\title{
Yeast lipases: enzyme purification, biochemical properties and gene cloning
}

\author{
Jyoti Vakhlu* \\ Department of Biotechnology \\ University of Jammu \\ Jammu-180006 ( J\&K) \\ India \\ Tel: 094191-17624 \\ E-mail: jyotivakhlu@yahoomail.com \\ Avneet Kour \\ Department of Biotechnology \\ University of Jammu \\ Jammu-180006( J\&K) \\ India \\ E-mail: avneetneeti@rediffmail.com
}

Keywords: Candida, Geotrichum, lipase, Trichosporon, yeast.

\begin{abstract}
Lipases are placed only after proteases and carbohydrases in world enzyme market and share about $5 \%$ of enzyme market. They occur in plants, animals and microorganisms and are accordingly classified as plant, animal and microbial lipases. Wherever they exist, they function to catalyze hydrolysis of triglycerides to glycerol and fatty acid. Like carbohydrases and proteases, lipases of microbial origin enjoy greater industrial importance as they are more stable (compared to plant and animal lipases) and can be obtained in bulk at low cost. Majority of yeast lipases are extracelluar, monomericglycoproteins with molecular weight ranging between $\sim 33$ to $\sim 65 \mathrm{kD}$. More than $50 \%$ reported lipases producing yeast, produce it in the forms of various isozymes. These lipase isozymes are in turn produced by various lipase encoding genes. Among many lipase producing yeasts Candida rugosa is most frequently used yeast as the source of lipase commercially. This review is aimed at compiling the information on properties of various yeast lipases and genes encoding them.
\end{abstract}

Lipases (EC 3.1.1.3) are a class of hydrolases that are primarily responsible for the hydrolysis of acylglycerides. They are ubiquitous and indispensable for the bioconversion of lipids (triacylglycerol) in nature. In addition to their biological significance, lipases hold tremendous potential for exploitation in biotechnology. They posses the unique feature of acting at the aqueous and non - aqueous interface which distinguishes them from esterases (Verger, 1997; Schmidt and Verger, 1998). The concept of lipase interfacial activity evolved from restriction of their catalytic activity to interface between lipid and water. The catalytic activity of lipases depends largely on the aggregated state of substrates. Experimental evidences suggest that the activation involves unmasking and structuring of enzyme-active-site, through conformational changes, that require presence of oil-in water droplets. Recent studies on the structure of several lipases have provided some clues for understanding their hydrolytic activity, interfacial activation and stereoselectivity of lipases (Kazlauskas and Bornscheuer, 1998). Enzymes such as proteases and carbohydrases have been used industrially for a number of years and corner the largest share of the world wide enzyme market. Whilst lipases at present account for less than $5 \%$ of the market, this share has the potential to increase dramatically via a wide range of different applications.

The lipases catalyze wide range of reactions, including hydrolysis, inter-esterification, alcholysis, acidolysis, esterification and aminolysis. They catalyse the hydrolysis of fatty acid ester bond in the triacylglycerol (TAG) and release free fatty acids (ffa) (Sheldon, 1993). The reaction is reversible; the direction of the reaction depends upon the water content available in the reaction. In low water media lipases catalyse esterification, transesterification and interesterification. Biochemical and molecular characterization of a number of lipases of different sources has brought to light great deal of heterogeneity in them with regard to specificity, amino acid sequence and catalytic properties. Based on the inhibition of their enzyme activity by chemical modification, lipases were initially classified as serine hydrolases. Serine present attheir active site has been shown to be enclosed in the highly conserved domain and represents the only common feature shared by all determined lipases sequenced so far (Antonian, 1988).

*Corresponding author 
Although lipases can be produced easily on a large scale by growing microorganisms in a fermentor, yet their use was, till recently confined largely to oleo-chemistry and dairy based industry. However the last quarter of the $20^{\text {th }}$ century has witnessed unprecedented use of lipases in biotechnology, manufacture of pharmaceuticals and pesticides, single cell protein production, biosensor preparation and in waste managementetc(Torossianet al. 1991; Gandhi, 1997; Yadavet al. 1998, Pandey et al. 1999; Jaeger et al. 1999; Saxena et al. 1999).Lipases have become an integral part of the modern food industry and are used in the preparation of a variety of products including fruit juices, baked food, vegetable fermentation and dairy enrichment. They are also used in leather industry for processing hides and skins (bating) and for treatment of activated sludge and other aerobic waste products where they remove the thin layer of the fats and by so doing provide for oxygen transport. The lipid digesting preparation is employed in sewage disposal plants in USA under the trade name lipase M-Y (Meito Sangyo Co., Nagoya Japan). Lipases may also assist in the regular performance of anaerobic digesters. Nearly 1000 tonnes of lipase are used annually in detergent industry, primarily as lipid stain digesters. They also are used as flavour development agents in the preparation of cheese, butter and margarine. These hydrolases are endowed with substrate specificity that surpasses any known enzyme. This property confers to them the potential that is literally boundless. The growing interest in lipases is reflected by publication of an average of 1000 research papers per year (Pandey et al. 1999), on different aspects of these enzymes.

Some of the common sources of lipases are tabulated in Table 1. Pancreatic lipase of porcine origin is one of the earliest recognized and is still the best known lipase. Plant lipases are not used commercially; the animal and microbial lipases are used extensively. The most important source of animal lipase is the pancreas of cattle, sheep, hogs and pigs. The disadvantage with pancreatic//animal) lipases is that they cannot be used in the processing of vegetarian or kosher food. Also, that these extracts contain components which have undesirable effect. The pig pancreatic extract contains trypsin, which produces bitter tasting amino acids. They are also likely to contain residual animal viruses, hormones, etc.

Microbes are major source of the 100 or so enzymes produced industrially for reasons mentioned above. Yeast has been used in food and other industries since ages. They have earned acceptability since long and are considered natural. Yeasts are also considered to be easy to handle and grow, in comparison to bacteria (Kademi et al. 2003).

Among microbial lipases extensive reviews have been written on bacterial lipases (Jaeger et al. 1999; Arpigny and Jaeger, 1999). Yeast lipases have received a raw deal despite the fact that Candida rugosa is the most frequently used organism for lipase synthesis. Benjamin and Pandey (1998) have written a review exclusive on Candida rugosa lipase. The information on numerous other yeast lipases is scattered. This communication is aimed at organizing the literature available on other yeast lipases. The areas reviewed are application, protein purification, and biochemical properties of yeast lipases and characterization of genes encoding these enzymes.

\section{YEAST LIPASES}

\section{Sources and application}

Lipases produced by various yeasts have been tabulated in Table 2.

The lipase produced by Candida rugosa is fast becoming one of the most industrially used enzymes. This is because of its use in avariety of processes due to its high activity, both in hydrolysis as well as synthesis (Redondo et al. 1995). A Japanese company has used the Candida rugosa lipase for production of fatty acids from castor bean long back in 1985 (Macrae and Hammond, 1985). Pandey et al. (1999) investigated the production of flavour in concentrated milk and creams by using microbial lipases. Organolephtically each lipase develops a characteristic flavour. The Candida rugosa lipase was rated the most suitable lipase in this case. Candida antarctica AY30 immoblised lipase has been used for esterification of functional phenols for synthesis of lipophillic antioxidants subsequently used in sunflower oil (Pandey et al. 1999). Uppenberg and co workers (1994) developed Candida antarctica lipase into recombinant enzyme used for detergent formulation. The extra-cellular lipase produced by the asporogenic Candida cylindracea ATCC 14830 (CCL/CRL) hydrolyses triglycerides without specificity, both in attacked position of the glycerol molecule and in the nature of fatty acid released. This relaxed specificity vis-àvis other lipases makes CCL/CRL particularly useful for industrial application (Lotti et al. 1993).

In detergent industry, lipases find use as lipid stain digesters. Lipases from Candida cylindracea and Candida lypolytica (now Yarrowia lipolytica) are choice enzymes for the purpose (Pierce et al. 1990; Batenburg et al. 1991).Polyglycerol and carbohydrate fatty acid esters are widely used as industrial detergents and as emulsifiers in variety of food formulations (low fat spreads, ice creams, mayonnaise). Enzymatic synthesis of functionally similar surfactants has been carried out at moderate temperature $\left(60^{\circ} \mathrm{C}-80^{\circ} \mathrm{C}\right)$ with excellent regioselectivity. Recently, Unichem International has launched production of isopropyl myristate, isopropyl palmitate and 2ethylpalmitate for use of emollient in personal care products. Presently these compounds are being manufactured enzymatically using $C$. cylindracea lipase in batch bioreactor.

A promising new field is the use of microbial lipase as biosensors. Biosensors can be chemical or electronic in nature. An important analytical use of lipases is 
Table 1. Common mammalian, fungal and bacterial sources of lipases.

\begin{tabular}{|c|l|}
\hline Source & \multicolumn{1}{|c|}{ Name } \\
\hline Mammalian & $\begin{array}{l}\text { Human Pancreatic Lipase } \\
\text { Horse Pancreatic Lipase } \\
\text { Pig Pancreatic Lipase } \\
\text { Guinea Pig Pancreatic Lipase }\end{array}$ \\
\hline Fungal & $\begin{array}{l}\text { Rhizomucormeihei } \\
\text { Pencilliumcamberti } \\
\text { Humicolalanuginosa } \\
\text { Rhizopusoryzae } \\
\text { Aspergillus niger } \\
\text { Candida rugosa* } \\
\text { Candida antarctica Lipase A* } \\
\text { Candida antarctica Lipase B * } \\
\text { Geotrichiumcandidum* }\end{array}$ \\
\hline Bacterial & $\begin{array}{l}\text { Chromobacteriumviscosum } \\
\text { Pseudomonas cepacia } \\
\text { Pseudomonas aeruginosa } \\
\text { Pseudomonas fluorescens } \\
\text { Pseudomonas fragi } \\
\text { Bacillus thermocatenulatus } \\
\text { Staphylococcus hyicus } \\
\text { Staphylococcus aereus } \\
\text { Staphylococcus epidermidis }\end{array}$ \\
\hline & \\
\hline Staphos
\end{tabular}

* indicates yeast lipases. (http://www.au-kbc.org/beta/bioproj2/sources.htm)

determination of lipids for clinical purpose (Pandey et al. 1999). The basic concept is to utilize a lipase to generate glycerol from triacylglycerol and quantify the released glycerol or alternatively the non-esterified fatty acid by chemical and enzymatic method. This principal enables physicians precisely to diagnose patients with cardiovascular complaints. Non-specific lipases, especially of Candida rugosa with high specific activity has been selected to allow rapid liberation of glycerol Candida rugosa lipase biosensor, which optically conjugates to biorecognition group in DNA, has been developed as probe by Pittner et al (1995,cf. Pandey et al. 1995).

The application of lipases in organic synthesis is tremendous. Stereoselectivity of lipases for resolution of racemic acid mixture in immiscible biphasic system has been demonstrated. Efficient kinetic resolution processes are in vogue for the synthesis of Niknomycin-B, nonsteroid anti-inflammatory drugs Naproxen, ibuprofen, suprofen and ketoprofen, the potential antiviral agent lamividine (that can also be used against HIV) and enantiospecific synthesis of antitumour agents alkaloids, antibiotics and vitamins (Pandey et al. 1999). Hernaiz et al. (1997) have isolated two iso-forms, labelled A and B from Candida rugosa that are stereoselective.

Preparation of optically active amines that are intermediate in preparation of pharmaceuticals and pesticides have been described by Smidt and his coworker (1996). This involved reacting stereospecific $\mathrm{N}$-acylamines with lipase preferably from $C$. antarctica. In an attempt to determine substrate specificity of lipases, alkyl esters of 2 aryl- propionic acid, a class of non-steroid anti- inflammatory drugs were hydrolysed with Candida rugosa lipase. All transformations were found to be highly selective. Lipases are also used for enantiospecific catalysis. The stereo selective enatio-discrimination of Candida rugosa lipase yielded optically pure propionic acid derivative in S-form. The S-form was then converted to corresponding $\mathrm{R}$ form, which was effective against the insect pest Tetramuchus (Pandey et al. 1999).

Triglycerides, steryl esters, resin acids, free fatty acids and sterols which are lipophylic extractives (/extracts) of wood (commonly referred to as pitch or wood resin) have negative impact on paper machine run ability and quality of paper. Kontkanen and his group (2004) in their study tested 19 commercial lipase preparations able to show degradation of steryl esters. They found lipase preparations of Pseudomonas sp. Chromobacteriumviscosum and Candida rugosa were shown to have highest steryl esterase activity. All the three enzymes were able to hydrolyse steryl esters totally to completion in presence of a surfactant (thesit). Preliminary characterization of enzymatic activity revealed that the lipase preparation of Pseudomonas sp. could be the most potential industrial enzyme but among yeast Candida 
rugosa lipase (CRL) ruled the roost (Kontkanen et al. 2004). To introduce polymer to cellulosic material a new approach was developed by Gustavsson et al. (2004) using ability of a cellulose binding module of Candida antarctica lipase $\mathrm{B}$ conjugate to catalyze ring opening polymerization of epsilon-caprolactone in close proximity to cellulose fiber surface. Wang et al. (2003) demonstrated effective biocatalysis also by Candida antarctica Lipase (CAL B) in resolution of several 1-or 2-hydroxyalkanephosphonates. The enaniomers of phosphogabob and fosfomycin were prepared using CALB-mediated resolution as key step Table 3 enumurates some selected yeast lipases which are already being produced commercially (Kazlauskas and Bornscheuer, 1998).

\section{PROTEIN PURIFICATION AND BIOCHEMICAL PROPERTIES}

Like many other microbial lipases, yeast lipases are also purified by two major purification techniques i) precipitation techniques (with salts, alcohols etc.) and, ii) chromatographic techniques (ionic, hydrophobic interaction, affinity and molecular sieving). Table 3 summarizes some of the properties of reported yeast lipases.

\section{Candida Spp.}

There are several reports on the multiple forms of lipases produced by the microorganism. This multiplicity has been ascribed to post-transcriptional processing, existence of different genes, deglycosylation etc. Among yeasts Candida aldicans, Candida Antarctica, Candida rugosa, Geotrichum asteroids, Geotrichumcandidium, Trichosporonfermentans, Saccharomycopsis lipolytica, Yarrowia lipolytica (formally Candidaparalipolytica), etc. are reported to produce multiple lipase forms.

Various strains of Candida rugosa / cylindracea (L.1754, ATCC 14830,DSMZ 2031) are known to produce lipase. Purification and characterization has been reported for a number of them. Two distinct lipases from Candida rugosa (C. cylindrcea L.1754) were identified and separated by high-resolution anion exchange column mono Q after ethanol extraction of crude lipase. Lipase I eluted at 0.05 $\mathrm{MNaCl}$ whereas lipase II eluted at $0.15 \mathrm{MNaCl}$ from this column. The less anionic nature of lipase I was confirmed by native polyacryamide gel electrophoresis and isoelectricfocusing. Both the proteins have apparent molecular weight of $58 \mathrm{kD}$ on SDS-PAGE. The isoelectric focusing point of lipase I and II are $\sim 5.8$ and $~ 5.6$ respectively (Veeraragavan and Gibbs, 1989). The same year Shaw and Chang (1989) demonstrated presence of three distinct lipase forms A, B and $\mathrm{C}$ in Candida rugosalipase supplied by Sigma Co. All the three forms exhibit significant lipolytic activity. All the three lipases bind to DEAE-Sepharose pre-equilibrated with $0.1 \mathrm{M}$ phosphate buffer $\mathrm{pH} 6.8$ but lipase A bound weakly to this column and could be eluted with $0.2 \mathrm{M}-0.25 \mathrm{MNaCl}$.
Lipase B and C were co-eluted with $0.3 \mathrm{M}-0.6 \mathrm{MNaCl}$. Shaw and Chang (1989) proposed that lipase A and C correspond to lipase II and I reported by Veeraragavan and Gibbs (1989). They further proposed that lipase B was not discovered by these workers probably because they transformed it into lipase I by ethanol treatment of crude lipase powder used. The apparent molecular weights of lipase A, B and C was found to be $\sim 362, \sim 200$ and $\sim 143$ KD. The results from SDS-PAGE indicate that lipase A and $\mathrm{C}$ are composed of subunits of the same molecular weight i.e. $62 \mathrm{KD}$. It is quite possible that lipases $\mathrm{A}, \mathrm{B}$ and $\mathrm{C}$ are hexamer, trimer and dimer of the same subunit. Lipase A has higher optimal reaction temperature and better thermal stability compared to that of lipase $\mathrm{C}$. The optimal $\mathrm{pH}$ for lipase $\mathrm{A}$ and $\mathrm{C}$ are 7.0 and 5.0 respectively. Lipase $\mathrm{A}$ and $\mathrm{C}$ exhibit higher lipolytic activity on esters with intermediate acyl chain length, Not much is known about, characteristics of lipase B and mechanism of its transformation from lipase I reported by Veeraragavan and Gibbs (1989).

Five years latter Chang and his group (Chang et al. 1994) reported that PAGE pattern of lipolytic enzymes obtained from three commercial samples (different manufacturers) of Candidarugosa lipase differed. They studied the effect of culture conditions on the production of lipase from Candida rugosa (ATCC 14830) and proposed that culture conditions not only influence the production of lipase but also changed the pattern of formation of multiple forms of lipase. They showed presence of tween 20 and 80 in culture media for Candidarugosa resulted in production of various forms of lipase showing different substrate specificities and thermal stabilities. The results suggest that the specificity and stability of lipase preparation can be modulated by culture condition. Chang et al. (1994) proposed that multiple patterns of lipases could result from change in gene expression, variable percentage of covalently linked carbohydrates, partial proteolysis and posttranscriptional modifications. Hitherto five genes belonging to lipase gene family, have been isolated from Candidarugosa, which suggest that some of the multiple lipase forms that Chang and his group have identified, are the result of change in gene expression.

Lotti and her group in the University of Milan, Italy have been studying various aspects of lipase production by Candida rugosa/cylindracea for about a decade. They (Lotti et al. 2001) undertook a flow cytometric study to evaluate growth-production process of Candida rugosa cells of different culture media. The yeast follows a complex pattern of lipase production depending on the presence of multiple lipase encoding genes whose expression is modulated by Carbon source. The C-source employed during fermentation can act as a repressor e.g. glucose, sorbitol. Neutral substrates may be successfully employed in two-step fermentation, where the first step of biomass growth is followed by the induction of lipase gene expression. Most of the lipases including those from Candidarugosa are glycosylated in conformity with rest of the lipases Candidarugosa lipases are widely used in 
Table 2.Reported lipase producing yeasts, their cellular localization and number of lipase isozymes produced by each yeast.

\begin{tabular}{|c|c|c|c|}
\hline Source & Cellular - location & Isoforms & Reference \\
\hline Arxulaadeninivorans & Extra-cellular & $1^{*}$ & Boer et al. 2005 \\
\hline Candida albicans & Extra-cellular & $10^{*}$ & Hube et al. 2000 \\
\hline Candida antarctica & Extra-cellular & $2^{*}$ & $\begin{array}{l}\text { Høegh et al. } 1995 \\
\text { Rotticci et al. } 2001\end{array}$ \\
\hline Candida ernobii & Extra-cellular & 1 & $\begin{array}{l}\text { Pignede et al. } 2000 a \\
\text { Pignede et al. } 2000 \mathrm{~b}\end{array}$ \\
\hline Candida parapsilosis CBS 604 & Cell bound & $1^{*}$ & Neugnot et al. 2002 \\
\hline $\begin{array}{l}\text { Candida rugosa/Cylindracea } \\
\text { ATCC } 14380 \\
\text { DMS } 2031 \\
\text { L } 1754\end{array}$ & $\begin{array}{l}\text { Extra-cellular } \\
\text { Extra-cellular } \\
\text { Extra-cellular }\end{array}$ & $\begin{array}{l}5^{*} \\
3 \\
2\end{array}$ & $\begin{array}{l}\text { Brocca et al. } 1995 \\
\text { Benjamin and Pandey, } 2001 \\
\text { Veeraragavan and Gibbs, } 1989\end{array}$ \\
\hline Candida curvata & - & - & Lazar and Schroder, 1992 \\
\hline Candida tropicalis & - & - & Lazar and Schroder, 1992 \\
\hline Candida deformans CBS 2071 & Extra-cellular & $3^{*}$ & Bigey et al. 2003 \\
\hline Geotrichum asteroids FKMF 144 & Extra-cellular & 2 & Kazanina et al. 1981 \\
\hline $\begin{array}{l}\text { Geotrichumcandidum } \\
\text { ATCC } 34614 \\
\text { NRCC205002 } \\
\text { NRRL Y-552 } \\
\text { NRRL Y-533 } \\
\text { CMICC } 335426 \\
\text { ATCC } 66592\end{array}$ & Extra-cellular & $\begin{array}{l}2^{*} \\
2^{*} \\
2^{*} \\
2^{*} \\
2 \\
2\end{array}$ & $\begin{array}{l}\text { Shimada et al. } 1990 \\
\text { Bertolini et al. } 1994 \\
\text { Bertolini et al. } 1994 \\
\text { Bertolini et al. } 1994 \\
\text { Charton et al .1992 } \\
\text { Jacobsen and Poulsen, } 1992\end{array}$ \\
\hline Geotrichum sp. FO401B & Extra-cellular & 2 & Ota et al. 2000 \\
\hline Kurtzmanomyces sp. I-11 & Extra-cellular & 1 & Kakugawaet al. 2002 \\
\hline Kluyveromyces lactis & Extra-cellular & $1^{*}$ & Oishi et al.1999 \\
\hline Saccharomysiscerevisiae & - & - & Oishi et al.1999 \\
\hline Saccharomysifibuligera & - & - & Pandey et al.1999 \\
\hline Trichosporonasteroides & Extra-cellular & 1 & $\begin{array}{l}\text { Dharmsthiti and Ammaranond, } \\
1997\end{array}$ \\
\hline Trichosporoncutaneum & Extra-cellular & - & Chen et al.1993 \\
\hline $\begin{array}{l}\text { Trichosporonfermentans } \\
\text { WU-C12 }\end{array}$ & Extra-cellular & $2^{*}$ & $\begin{array}{l}\text { Chen et al. } 1993 \\
\text { Chen et al. } 1994 \\
\text { Arai et al. } 1997\end{array}$ \\
\hline Yarrowia lipolytica & Extra-cellular and cell bound & $2,1^{*}$ & $\begin{array}{l}\text { Ota et al. } 1982 \\
\text { Destain et al. } 1997 \\
\text { Pignede et al. } 2000 \mathrm{a} \\
\text { Pignede et al. } 2000 \mathrm{~b}\end{array}$ \\
\hline
\end{tabular}

* bookmarks the isozymes, wherein the genes encoding them have been identified, isolated and cloned. 
biotransformations on account of their thermal stability and substrate specificity. The percentage and nature of carbohydrate attached seem to be important in structure interaction of glycoprotein with oil water interface, thermal stability, hydrophobic hydrophilic interaction, and over all catalytic activity of lipases.

Elimination of non-covalently bound sugar produces diminution in enzymatic activity in hydrolysis of tributyrin, in synthesis of heptyl oleate and in thermal stability. The equilibrium of this enzyme with lactose or with dextran produces partial reactivation of the biocatalyst.

Benjamin and Pandey (2001) isolated and characterized three distinct forms of lipases from Candida rugosa (DM 2031), produced in solid-state fermentation. Three distinct forms of extra-cellular lipase (lipA, lipB, and LipC) were isolated by ammonium sulphate precipitation, dialysis, ultra filtration and gel filtration using Sephadex-200. The purification was 43 -fold with specific activity $64.35 \mathrm{mg} / \mathrm{ml}$. SDS- PAGE of purified lipase revealed three distinct bands indicating the existence of three iso-forms with apparent molecular weight of 64,62 and $60 \mathrm{kD}$. All the three forms have optimal activity at $35-40^{\circ} \mathrm{C}$ and $\mathrm{pH} 7-8 . \mathrm{Ag}^{++}$and $\mathrm{Hg}^{++}$strongly inhibit the activity of all the iso -forms whereas $\mathrm{Ca}^{++}$and $\mathrm{Mg}^{++}$enhance the lipase activity. The activity of all the three forms was completely inhibited by serine protease inhibitors namely, -dichloroisocoumarin and pefabloc. Phenylmethanesulphonyl fluoride inhibited their activity partially.

Lopez et al. (2004) compared three pure isoenzymes from Candida rugosa (CRL: Lip 1, Lip 2 and Lip 3) in terms of their selectivity and reactivity in both aqueous and organic media. This analysis indicated that Lip 1 and Lip 3 have similar stability, lower than that of lip2. In aqueous media however Lip 3 was the most active enzyme so far as hydrolysis of P-niotrophenyl ester is concerned and Lip 1 showed highest activity on the hydrolysis of most assayed triaylglycerides. High difference in the isozyme was found in hydrolysis of triacylglycerides. Short, medium and long acyl chain triacylglycerides was preferred substrate for Lip 3, Lip 1 and Lip 2 respectively. In organic media Lip 1 and Lip 3 provided excellent results in terms of enantioselectivity in the resolution of ibuprofen (value over 0.90 ) and conversion, whereas initial esterification rate was higher for Lip 3, Lip 2 resulted in lower values of conversion, enantiomeric access and enantioselectivity. The performance of pure isozyme in enantioselectivity and esterification of substrate was compared with different CRL crude preparation with known isozymatic content and the different results could not be explained on their isoenzymatic profile.

As CRLs can be hardly separatedfrom each other and characterized as pure proteins, detailedinformation is available for only some of them. CRL1 over expressedin Pichiapastoris was found to exert highest activity on medium-chainsubstrates (C8-C10) in the hydrolysis of both triglyceridesand methyl-esters, whereas recombinantCRL4 and CRL2 overexpressed in Pichiapastoris acted preferentiallyon long-chain molecules (C16 - C18).A third isoform, CRL3, is characterized by itssignificant activity on short-chain soluble substrates and by its ability to hydrolyse cholesterol estersof long-chain fatty acids. Cholesterol esteraseactivity was also demonstrated more recently in CRL2 (Brocca et al. 2003).

\section{Geotrichum}

Couple of species of genus Geotrichum are known to produce lipases most of themextra-cellular. Tsujisaka et al. (1973) purified lipase of GeotrichumcandidumLink by means of ammonium sulphate fractionation, DEAE Sephadex chromatography and gel filtration of sephadex G100 and G-200. The purified enzyme was subsequently crystallized. The crystallized preparation was found to be homogenous electrophoretically as well as centrifugally. The molecular weight and pI value of the enzyme were estimated to be $\sim 55 \mathrm{kD}$ and $\sim 4.33$. The crystalline preparation contained about $7 \%$ carbohydrate and a very small amount of lipids. This lipase was active on olive oil at $\mathrm{pH} 5.6$ and 7.0 at $40^{\circ} \mathrm{C}$. This enzyme maintained its stability in the $\mathrm{pH}$ range of $4.2-9.8$ for $24 \mathrm{hrs}$. The enzyme is stable at temperature below $55^{\circ} \mathrm{C}$ for $15 \mathrm{~min}$.

Two forms of lipases have been isolated from Geotrichumcandidum ATCC 34614 by combining of ethanol precipitation and chromatography on Sephacryl HR anion exchange and polybuffer exchange 94 . The molecular weight of enzymes has been estimated to be $\sim 56 \mathrm{KD}$. The optimum $\mathrm{pH}$ value and isoelectric focusing point of the isoforms is 6.8 and 6.0 and 4.46, 4.56 for lipase I and II respectively. The enzymes are found to remain stable in the $\mathrm{pH}$ range 6.0 - 8.0. Monovalent ions had little effect on activity of both the enzyme whereas divalent ion at concentration above $50 \mathrm{mM}$ inhibited the activity in concentration dependent manner. At concentration less than $10 \mathrm{mM}$ ionic detergent sodium dodecyl sulphate completely inhibited lipase activity (Veeraragavan et al. 1990).

Like species of genus Candida, Geotrichumcandidum is also known to produce various forms of lipase. Purification and characterization of different lipase iso-forms produced by various strains of Geotrichumcandidum is difficult on account of overlapping in their physical and biochemical properties. At times the heterogeneity is result of the difference in glycosylation. The reports that appeared recently on substrate selectivity of apparently purified lipase iso-forms are contradictory.

Shimada et al. (1990) reported that there is no significant difference in the substrate selectivity of two lipase isoforms of Geotrichumcandidum ATCC 34614, although the two forms have slightly different stability and biochemical properties. In contrast, the lipase iso-forms (termed lipase A and B) from strain Geotrichumcandidum CMICC 335426 have shown to have markedly different substrate specificity (Sidebottom et al. 1990) These investigators also isolated 
Table 3.Selected examples of yeast that are used for production of lipases commercially with their commercial names and list of suppliers.

\begin{tabular}{|c|c|c|}
\hline Name & Commercial name & Commercial source \\
\hline $\begin{array}{l}\text { Candida cylindracea } \\
\text { (CRL) }\end{array}$ & $\begin{array}{l}\text { ChiroCLEC-CR } \\
\text { Lipase AY } \\
\text { Lipase MY, Lipase OF-360 } \\
\text { Chirazyme } ® \text { L-3 }\end{array}$ & $\begin{array}{l}\text { Atlus Biologics } \\
\text { Amano } \\
\text { Meito Sangyo } \\
\text { Boehringer Mannheim } \\
\text { Sigma }\end{array}$ \\
\hline $\begin{array}{l}\text { Geotricumcandidum } \\
\text { (GCL) }\end{array}$ & $\begin{array}{l}\text { Chirazyme®L-8 } \\
\text { SP 524, Lipolase } 尺\end{array}$ & $\begin{array}{l}\text { Boehringer Mannheim } \\
\text { Nova-nordisk }\end{array}$ \\
\hline $\begin{array}{l}\text { Candida antartica } A \\
(\mathrm{CAL}-\mathrm{A})\end{array}$ & $\begin{array}{l}\text { Chirazyme } ® \text { L-5, } \\
\text { SP526, }\end{array}$ & $\begin{array}{l}\text { Boehringer Mannheim } \\
\text { Nova-nordisk }\end{array}$ \\
\hline $\begin{array}{l}\text { Candida antartica A } \\
(\mathrm{CAL}-\mathrm{B})\end{array}$ & $\begin{array}{l}\text { Chirazyme }{ }^{\circledR L}-2 \\
\text { SP } 525 \text { or Novozym 435b }\end{array}$ & $\begin{array}{l}\text { Boehringer Mannheim } \\
\text { Nova-nordisk } \\
\text { Sigma }\end{array}$ \\
\hline $\begin{array}{l}\text { Yarrowia lipolytica } \\
\text { (earlier Candida lypolytica, CLL) }\end{array}$ & Lipase L & Amano \\
\hline
\end{tabular}

two isozymes from stain ATCC 34614 which showed selectivity similar to those of the two iso-forms isolated from the strain CMICC 335426. Moreover comparison of specificity profiles and partial peptide sequences revealed that lipase A is similar to lipase II and lipase B is similar to lipase I. The contradictory results about the substrate selectivity of various isozymes may be on account the different growth conditions employed by different investigators. Growth conditions are known to alter relative yields of lipases produced by Geotrichumcandidum. On the other hand, the presence of multiple, differentially expressed lipase genes coding for products having similar chromatographic properties cannot be ruled out. Two lypolitic enzymes were isolated from the culture fluid of yet other species of Geotrichum,Geotrichumasteroides by Kazanina et al. (1981). Lipase produced by Trichosporonheteromorphum ATCC 20001 were examined in media containing soyabean oil and residues but at present the strain ATCC 20001 has been reidentified as Geotrichumklebahnii. Using high-performance liquid chromatography Jacobsen and Poulsen (1992) isolated two lipolytic proteins with MW $\sim 61$ and $\sim 57 \mathrm{kD}$ from Sephadex G-100 fraction of extracellular lipase from Geotrichumcandidum ATCC 66592 were separated. Purified lipases were immunologically identical, but differed substrate specificity.

\section{Trichosporon}

Trichosporonis yet another yeast studied in detail for lipase production. So far four species of the genus are reported to produce lipase. Chen et al. (1992) isolated Trichosporonfermentans WU-C12 from soil that showed maximum lipase production $(128 \mathrm{U} / \mathrm{ml})$ after four days of growth at $30^{\circ} \mathrm{C}$. Of the various $\mathrm{C}$ sources tested for their effect on growth and lipase production, use of tung oil followed by olive oil $(3 \% \mathrm{~W} / \mathrm{V})$ resulted in highest lipase productivity $146 \mathrm{U} / \mathrm{ml}$ and $126 \mathrm{U} / \mathrm{ml}$ respectively. On the contrary, when cultured in media containing glucose as $\mathrm{C}$ source Trichosporonfermentans WU-C12 produced only 34 $\mathrm{U} / \mathrm{ml}$ lipase. Addition of glucose to corn steep -olive oil medium reduced the lipase production in Trichosporon unlike Yarrowia lipolytica (formally Candida paralypolytica, Saccharomycopsis lipolytica), and Geotrichumcandidum. These results suggest that the lipase produced byTrichosporonfermentans WU-C12 is constitutiveTrichosporonfermentans WU-C12 is reported to produce two types of extra cellular and three types of intracellular lipases (Chen et al. 1993). Chen et al. (1993) further subjected Trichosporonfermentans WU-C12 to UV rays, which resulted in the production of higher quantities of extra cellular lipase than the parental strain. They proposed that enhancement of lipase production in mutant could be because of improvement in utilization of wide range of $n$ - alkanes, permeability of lipase and lipase productivity per cell. The effect of surfactants on lipase production by Trichosporonfermentans WU-C12 was investigated. Addition of surfactants resulted in 2-3 times increase in extra cellular lipase activity. It was also observed that the total extra and intracellular activity was affected by the combination of surfactants and petroleum products used as Carbon source (Chen et al. 1994). These workers purified two types of extra-cellular lipases, lipase I and lipase II from this strain of Trichosporon by combining acetone precipitation with successive chromatography on butyl-toyopearl 650 MToyopearl HW-55 and Q - Sepharose FF. The molecular weight of lipase I was $\sim 53 \mathrm{kD}$ as estimated by SDS-PAGE and $\sim 160 \mathrm{KD}$ by gel filtration 
while that of lipase II was $\sim 55 \mathrm{kD}$ as estimated by SDSPAGE and $\sim 60 \mathrm{KD}$ by gel filtration. Both the lipases are stable in the $\mathrm{pH}$ range of $4.0-8.0$ for $24 \mathrm{hrs}$ at $30^{\circ} \mathrm{C}$. Both lipase II and I seemingly are thermo stable. Lipase I was stable at $40^{\circ} \mathrm{C}$ for $30 \mathrm{~min}$ at $\mathrm{pH} 5.5$ and lipase II under same conditions remainsstable up to $50^{\circ} \mathrm{C}$. As far as their substrate specificity is concerned both lipases hydrolyse 1 , 2, 3 positions of triolein and cleave all the three ester bonds, irrespective of their position in triglyceride.

TrichosporonfermentansWU-C12 lipase (TFL I) is almost identical to Geotrichumcandidum lipase I and II which suggests similarity in their three dimensional structure. $G$. Candidum ATCC 34614 produces 2 or four kinds of monomeric lipases whereas Tichosporonfermentans WUC12 lipase I am trimer with molecular mass of $160 \mathrm{KD}$ as determined as by gel filtration. Difference in the number of subunits in mature lipases in both the genus lead to different substrate specificity. In addition difference of three amino acid residues and /or glycosylation might have an effect on unit structure of TFL GCL, II and I.

Another lipase producing species of Trichosporon is Trichosporonasteroids that was isolated from raw milk Dharmsthiti and Ammaranond (1997). The lipase was purified to homogeneity (eight fold) using various techniques including ammonium sulphate fractionation and gel filtration on Sephadex G200. The molecular weight of this lipase was estimated to be $\sim 37 \mathrm{KD}$ with temperature and $\mathrm{pH}$ optima of $60^{\circ} \mathrm{C}$ and 5.0 respectively. It maintains stability over wide range of $\mathrm{pH} 3.0$ to 10.0 and at temperature below $70^{\circ} \mathrm{C}$. It is not a metallo- 1 protein as metal ion chelators do not inhibit the enzyme activity. The recovery after purification was noticeably low which could be due to spontaneous aggregation of the enzyme that leads to reduced enzyme activity. Gel filtration pattern of the enzyme indicated a molecular mass of $200 \mathrm{kD}$, which is in contrast to the mass estimated by SDS PAGE. This difference is perhaps caused by aggregation of lipase molecules.

\section{Yarrowia lipolytica and other yeasts}

Several enzymes are secreted by Yarrowia lipolytica (earlier Saccharomycopsis lipolytica, Candida lipolytica, Candida paralipolytica) and lipase and esterase activities have been detected and analyzed in variousstudies (Sugiura et al. 1976; Ota et al 1982; Ota and Yamada, 1966). Lipase secretion was first reported in 1948 by Petersand Nelson (Pignede et al. 2000a). An extracellular and two cell-bound types of activitycorresponding to lipase I $(39 \mathrm{kDa})$ and lipase II (44 kDa) weredescribed by Ota and coworkers (Sugiura et al. 1976; Ota et al. 1982). Cell bound enzymes were purified from the organism with total recovery of $8 \%$ by chromatography on CM -Sepharose CL-6B, DEAE Seharose CL-6B and Sephadex G-100columns. The purified lipase requires oleic acid for the hydrolysis of triglycerides and hydrolyses tricaprylin at largest initial rate. Under experimental conditions the $\mathrm{pH}$ optima for hydrolysis of olive oil as substrate were about 8.0. Both enzymes remain stable for $20 \mathrm{~min}$ below $37^{\circ} \mathrm{C}$ and at $\mathrm{pH}$ ranging between $4.5-8.0$ for $22 \mathrm{hrs}$ at $5^{\circ} \mathrm{C}$ (Ota et al. 1982). The extracellularlipase required oleic acid as a stabilizeractivator, whereasthe cell-bound lipases did not and differed in several propertiesfrom the extracellular enzyme (Ota et al. 1984). Productionof the extracellular and cellbound enzymes were reported to dependon the Carbon and Nitrogen composition of the medium. Extracellularlipase was only detected in cultures grown with an organic nitrogensource, and lipase levels were shown to be modulatedby cell morphology. In minimal medium supplemented with $\mathrm{N}$-acetylglucosamineor citrate buffer, both of which promote dimorphic growth, higherlevels of cell-bound lipases were detected. However, no clearrelationship was established between the dimorphic state and lipaseproduction (Novotny et al. 1994). Like many others Ota et al. (1982) have demonstrated that media engineering can lead to increase in production of extracellular enzymes. Lipase II and I were purified nearly 69 and 58 fold respectively. Lipase I had optimum $\mathrm{pH}$ of 8.2 for hydrolysis of olive oil as substrate and 7.5 for tributyrin hydrolysis. Lipase II has $\mathrm{pH}$ optima 8.0 for olive oil, 7.5 for tributyrin and 7.0 for triolein hydrolysis. Ota et al. (1982) concluded that there is no significant difference in the enzymological properties of lipase II and I. They have proposed that one enzyme is modified protein of the other, and the modification is caused by enzymatic reaction or binding of some components. Strangely enough the extracellular lipase as well as the two purified cell bound lipases require oleic acid as a the lipase activator for hydrolysis of exogenous triglycerides but the cell bound lipase located on living yeast cell appeared not to have this requirement. Nterminal amino acid sequence of purified the $39 \mathrm{kDa}$ extracellular lipase (called lipase A) was determined by Kuno and Ota, 1996. Destain and coworkers isolated Yarrowia lipolyticastrains overproducing an extracellular lipase. The secreted lipase wasshown to have an apparent molecular mass of $38.5 \mathrm{kD}$, giving threeisofocusing (pIs) of 5.0, 5.2, and 5.4. The sequenceof the first 49 aa of the Nterminus was determined andfound to be identical to that of lipase A (Destain et al. 1997). This sequence is similarto that of cell-bound lipase I; however, the extracellular lipaseand lipase I are considered to differ in amino acid composition (Kuno and Ota, 1996).

Kluyveromyces lactis is yet another yeast that produces extra cellular phospholipase B (PBL) (Oishi et al. 1999). The enzyme purified to homogeneity from culture medium is highly glycosylated with apparent molecular weight of $160-250 \mathrm{kD}$. The enzyme has two $\mathrm{pH}$ optima, $\mathrm{pH} 2.0$ and $\mathrm{pH}$ 7.5. The enzyme was reported to have at acidic $\mathrm{pH}$ the enzyme hydrolyses all phospholipids substrates with out metal ion .On the other hand at alkaline $\mathrm{pH}$ it showed specificity for phosphatidylcholine and lysophosphatidylcholine and required $\mathrm{Ca}^{++}, \mathrm{Fe}^{+++}$or $\mathrm{Al}^{+++}$ for activity. The alkaline activity gets increased over 20 fold in presence of $\mathrm{Al}^{+++}$compared to the presence of $\mathrm{Ca}^{++}$. 
Table 4.Overview of various biochemical properties (molecular weight, optimum $\mathrm{pH}$ and temperature and pl values etc.) of selected lipases produced by yeasts.

\begin{tabular}{|c|c|c|c|c|c|}
\hline Yeast & $\begin{array}{l}\text { MW in } \\
\text { KD }\end{array}$ & $\begin{array}{c}\text { PH } \\
\text { optima }\end{array}$ & $\begin{array}{l}\text { Stable pH } \\
\text { range }\end{array}$ & $\begin{array}{c}\mathrm{T}^{\circ} \\
\text { optima }\end{array}$ & Reference \\
\hline Arxulaadeninivorans & 50 & 7.5 & - & $30^{\circ} \mathrm{C}$ & Boer et al. 2005 \\
\hline Candida albicans ATCC 36082 & 38 & - & - & - & $\begin{array}{l}\text { Fu et al. } 1997 \\
\text { Hube et al. } 2000\end{array}$ \\
\hline Candida antarctica & 33 & - & - & & $\begin{array}{l}\text { Høegh et al. } 1995 \\
\text { Rotticci et al. } 2001\end{array}$ \\
\hline Candida cylindracea L1754 & $\begin{array}{l}\text { L1- } 58 \\
\text { L2- } 58\end{array}$ & - & $5.8-6.8$ & - & $\begin{array}{l}\text { Veeraragavan and Gibbs, } \\
1989\end{array}$ \\
\hline $\begin{array}{l}\text { Candida. Cylindracea } \\
\text { Commercial preparation }\end{array}$ & $\begin{array}{l}\text { LA-62 } \\
\text { LB- } 62 \\
\text { LC-62 }\end{array}$ & $\begin{array}{l}7.0 \\
5.0\end{array}$ & - & - & Shaw and Chang, 1989 \\
\hline Candida. rugosa ATCC 14380 & 60 & 5.0 & - & - & Lotti et al. 1993 \\
\hline Candida. rugosa DMS 2031 & $\begin{array}{l}\text { Lip A-64 } \\
\text { LipB- } 62 \\
\text { LipC- } 60\end{array}$ & $\begin{array}{l}7.8 \\
7.8 \\
7.8\end{array}$ & - & $35-40^{\circ} \mathrm{C}$ & Benjamin and Pandey, 2001 \\
\hline Geotrichumcandidum link & 55 & $5.6-7.0$ & $4.2-9.8$ & $40^{\circ} \mathrm{C}$ & Tsujisaka et al. 1973 \\
\hline $\begin{array}{l}\text { Geotrichumcandidum } \\
\text { ATCC } 34614\end{array}$ & $\begin{array}{l}\text { Lip } 156 \\
\text { Lip2 } 56\end{array}$ & $\begin{array}{l}6.8 \\
6.0\end{array}$ & $6.8-8.0$ & - & Veeraragavan et al. 1990 \\
\hline Kluyveromyces lactis & $160-250$ & $2.0-7.5$ & - & - & Oishi et al. 1999 \\
\hline Kurtzmanomyces sp. I-11 & 49 & $1.9-7.2$ & below 7.1 & $75^{\circ} \mathrm{C}$ & Kakugawa et al. 2002 \\
\hline Saccharomyces cerevisiae & 63 & & & & Oishi et al. 1999 \\
\hline $\begin{array}{l}\text { Yrrowia .lipolytica } \\
\text { (formally Saccharomycopsis lipolytica, Candida } \\
\text { lipolytica) }\end{array}$ & $\begin{array}{l}\text { Lip 1-39 } \\
\text { Lip-44 }\end{array}$ & $\begin{array}{l}8.2 \\
8.0\end{array}$ & $4.5-8.0$ & $37^{\circ} \mathrm{C}$ & Ota et al. 1982 \\
\hline $\begin{array}{l}\text { Trichosporonfermentans } \\
\text { WU-C12 }\end{array}$ & $\begin{array}{l}\text { Lip 1-53 } \\
\text { Lip2- } 55\end{array}$ & 5.5 & $4.0-8.0$ & $40^{\circ} \mathrm{C}$ & Arai et al. 1997 \\
\hline Trichosporonasteroides & 37 & 5.0 & $3.0-10.0$ & $50^{\circ} \mathrm{C}$ & $\begin{array}{l}\text { Dharmsthiti and } \\
\text { Ammaranond, } 1997\end{array}$ \\
\hline
\end{tabular}

a: 146 hrs of culture.

An extracellular lipase produced by the glycolipidproducing yeast Kurtzmanomyces sp. I-11 was purified by ammonium sulfate precipitation and column chromatographies on DEAE-Sephadex A-25, SP-Sephadex C-50, and Sephadex G-100 (Kakugawaet al. 2002). Its molecular mass was estimated to be approximately $49 \mathrm{kDa}$. By SDS-PAGE and optimum temperature for the activity was $75^{\circ} \mathrm{C}$. The activity was very stable at temperatures below $70^{\circ} \mathrm{C}$, the enzyme was in $\mathrm{pH}$ range of $1.9-7.2$ and stable at $\mathrm{pH}$ below 7.1. N-terminal sequence of the Kurtzmanomyces lipase was found to be similar to that of lipase A from Candida antarctica, though the $\mathrm{pH}$ profiles of the two lipases were significantly different (Kakugawa et al. 2002). Overview of biochemical properties of lipases and their isozymes has been given in Table 4.

\section{GENE CLONING}

In view of wide application of lipases referred to above and, difficulties in purifying their various isozymes due to their overlapping biochemical properties and obtaining these enzymes in bulk, attempts have been made to directly 
clone genes encoding them. It started with the primary objective to unravel the peptide structure of the enzyme, which is required to understand the molecular mechanism underlying the catalytic reaction and the relationship between the structure and function of lipase. Lipases gene of number of yeasts have been cloned and expressed, hyper expressed and bioengineered.

\section{Candida}

Lotti et al. (1993) reported that lipases of Candida cylindracea are encoded by multiple genome sequences, now on the basis of DNA-DNA homology at least seven are presumed to be present. Brocca et al. (1995) isolated and cloned 5 different forms of lipase from the species. The five-lipase genes comprising lipase gene family of Candida rugosa exhibit $80-88 \%$ pair wise identity, in nucleotide sequence. All genes encoding these isozymes are located on the same chromosome, which suggests their origin through gene duplication. Expression of cloned genes of genus candida is demanding due to strong codon bias in candidaspp. as universal leucine sequence codon CUG is used for serine (Ohama et al. 1993). CUG is used with high frequency ( $3 \%$ of the codon) in LIPI of Candida cylindracea including those corresponding to catalytic site. All the lipase sequences show distinct pattern for several restriction sites and not minor variation as would be expected in case of alleles. Sequence analysis performed on 5 fully sequenced genes demonstrated that the highest identity between any two-lipase genes is $88 \%$, a value less than usually observed in allelic variants of the same gene. The available sequences of CRL correspond to isozymes derived from the strain ATCC 14830. The inconsistencies in catalytic properties reported from different laboratories are due to presence of different lipase proteins in Candida cylindracea whose composition and ratio may be different in different commercial lipase preparations, possibly depending on the strain and media components used. Presence of multiple isoforms of lipases in Candida spp. is well established (Chang et al. 1994). Lotti and Alberghina (2003) indicated that CRL- encoding genes are subjected to regulation at the level of transcription depending on the composition of culture medium and the physiology of culture growth. This complex family of enzymes provide Candidarugosa cells with large and versatile pool of catalysts to suit the composition and environment of the culture media. However significance of lipases for the growth of Candida rugosa growth far from clear at present. The heterologous expression of cloned genes in host cells is desirable in the case of CRLs not only because of the well known advantages it offers in making large amount of purified enzymes available but also because it seems to be the only feasible approach to obtain pure CRL isoforms without the need of any sophisticated purification techniques required to separate similar proteins. Compared to commercial lipase preparation the recombinant Lip I showed a comparable activity towards triacylglycerides different in acyl group chain length and various methylesters differing in acyl group chain length (Brocca et al.
1998). Secretion of 200 ug lipase $\mathrm{ml}(-1)$ culture was achieved in sorbitol - based medium, in batch cultivation of Pichiapastoris expressing Candida rugosa lipase I (CRLI) (Passolunghi et al. 2003). These workers found that the large amount of recombinant protein was retained intracellularly throughout the fermentation pointing to transport step as a major bottleneck. To monitor the product localization and amount a translational fusion product with green fluorescent protein (GFP) was constructed that was expressed and translated by this group.

A lipase encoding gene was isolated from the pathogenic yeast Candida albicans (ATCC 36082) by transforming the lipase minus strain of Saccharomyces cerevisiae with genomic library of Candida albicans and screening for lipolytic activity ( $\mathrm{Fu}$ et al. 1997). Two identical clones exhibiting lipolytic activity were identified. Their nucleotide sequence analysis identified an ORF encoding a protein of 351 amino acid residues. The sequence contained the Gly-X-Ser-X-Gly- motif found in all prokaryotic and eukaryotic lipases, suggesting a similar activity for encoded the proteins. Southern analysis, using this lipase as probe, has suggested that lipase gene may be present in Candida glabrata, Yarrowia lipolytica (formally C. parapsilosis), Candida tropicalis, Candidakrusci but not in,Candida pseudotropicalis or Saccharomyces cerevisiae. Northern blot analysis has shown that expression of lip I transcript is detected only when Candida albicans was grown in media containing tween 80 , other tweens or triglycerides as the sole carbon source. Whereas Sabouraud Dextrose broth or yeast/peptone/dextrose and carbohydrate supplementation inhibited LIPI expression. Hube et al. (2000) have cloned and characterized 10 lipase genes in Candida albicans. The ORF of all the reported Candida albicans lipase genes are 1281 - 1416 bp long and encode highly similar proteins having up to $80 \%$ identical amino acid sequence. Each deduced lipase sequence has conserved lipase motif, 4 conserved putative $\mathrm{N}$-glycosylation sites and similar hydrophobicity profiles. Lip 3 - Lip 6 is expressed in all media at the times of growth when tested by Northern blot and PCR analysis. Lip 1, 2, 4, 5, 6, and 8 were expressed in media having tween 40 as the sole carbon source. These genes are also expressed in media deficient in lipids. Transcripts of most lipase genes were detected during yeast to hyphal transition. Lip 5, 6, 8, and 9 were found to express during experimental infection of mice. These data reveal lipid independent, highly flexible in-vitro and invivo expression of large number of Lip genes, possibly reflecting broad lipolytic activity, which may contribute to the persistence and virulence of Candida albicans in human tissue. Stehr et al. (2004) investigated expression pattern of multigene family of Candida albicans using reverse transcription polymerase chain reaction in experimental infections and in samples of patients suffering from oral candidosis. The finding illustrate that individual lipase genes are differentially regulated in a mouse model system. This study indicated that the lipase gene expression profile depended on stage of infection rather than on organ localization. The temporal regulation of lipase gene 
expression was also detected in an experimental model of oral candidosis.

Candida deformans CBS 2071 extra-cellular lipase has been cloned by complementation in accharomycecerevisiae with the genomic library of Candida deformans (Bigey et al. 2003). Three members of the lipase gene family CdLIP1, CdLIP2 and CdLIP3 were cloned and characterized. The MADLI-TOF data suggests that it is LIPI that produces the extra-cellular lipase. Each deduced lipase sequence has a Glu-His-Ser-Leu-Gly- (Gly-/Ala)-Ala conserved motif, eight cysteine residues and encodes a Nterminal sequence. These lipases were very similar to lipases from the related yeast Yarrowia lipolytica. Significant homologies were found with some other yeasts and fungi.

Neugnot et al. (2002) cloned and the over expressed the genecoding lipase from Candida parapsilosis CBS 604. Two ORFs (CpLIP1 and CpLIP2) wereisolated and the deduced 465-amino-acid protein sequences containedthe consensus motif (G-X-S-X-G) which is conserved among lipolyticenzymes. Only one of the two deduced proteins (CpLIP2) containedpeptide sequences obtained from the purified lipase/acyltransferase.Homology investigations showed that CpLIP2 has similaritiesprincipally with 11 lipases produced by Candida albicans (42 - 61\%)and the lipase A from Candida antarctica (31\%) but not withthe other lipases sequenced so far. Both CpLIP1 and CpLIP2 were expressed in Saccharomyces cerevisiae, but only CPLIP2 coded for an active protein. The substrate specificity and thecatalytic behavior of purified recombinant CpLIP2, with or withouta C-terminal histidine tag, were not changed compared to thoseof the native lipase.

Two lipases lipase A and B have been cloned and expressed by an extremophile yeast Candida antarcticaby Høegh et al. (1995) and have been expressed in Aspergillus oryzae. C. antarctica lipase A has also been cloned and expressed in Pichiapastoris under AOX 1 promoter by RotticciMulder and his group (2001).

\section{Geotrichum}

The yeast Geotrichumcandidum produces isozymes in culture medium that show close physical and biochemical properties but are different as for as substrate specificities are concerned. Shimada et al. (1989) isolated the lipase encoding cDNA clone of Geotrichumcandidum ATCC 34614 (Geo) from the Geo. cDNA library by colony hybridization. The library was probed by ${ }^{32} \mathrm{P}$ labeledoligonucleotides corresponding to a partial amino acid sequence of this enzyme. The nucleotide sequence of this cDNA determined by dideoxy chain termination method. The deduced amino acid sequence from cDNA coincided with the sequence of the protein. The cloned cDNA coded a protein of 554 amino acids and a hydrophobic signal sequence of 19 amino acids.
Geotrichum lipase contains the Gly-X-Ser-X-Gly sequence, which is believed to form part of the interfacial lipid recognition site. Use of this cDNA as probe during Southern DNA analysis of Geotrichumcandidum genome indicated existence of two genes on the chromosome of the yeast. Following these leads two forms of lipase (lipase I and II) were actually isolated and purified from this yeast. The two lipases isoenzymes have similar amino acid composition but different terminal sequences not found in the primary structure of lipases I deduced from the cDNA sequence. This confirmed the presence of two different lipase genes and ruled out the possibility of the formation of observed multiple forms by proteolytic digestion (Sugihara et al. 1990). The same year Shimada et al. (1990) cloned and sequenced the cDNA for lipase II of Geotrichumcandidum. They found the overall length of the two lipases is same, the overall identity being $84 \%$. Homology search has indicated that the Geotrichumcandidum lipase and Candida cylindracea lipase are homologous enzymes and are members of the cholinesterase family. Three years latter, Nagao et al. (1993) using the previously isolated lipase I and II cDNAs as probe isolated two chromosomal lipase genes lip $1 \& 2$, encoding lipase I and II. Both the genes were reported to contain contained 5'- and 3'- flanking regions in addition to coding region. Both the coding regions contained no introns and exhibit $86 \%$ homology in nucleotide sequence. Vernet et al. (1993) cloned, and sequenced the gene encoding lipase II of Geotrichumcandidum strain ATCC 34614 (GCL II) after amplified using the polymerase chain reaction. The intron less lipase gene was expressed and secreted from Saccharomyces cerevisiae at approximately $5 \mathrm{mg} /$ liter of culture. Recombinant GCL II was purified by immunoaffinity chromatography and characterized using a combination of substrates and independent analytical methods. Bertolini et al. (1994) have reported that lipase iso-forms may be present in other Geotrichumstrains as well, but their purification and isolation is difficult on account of their overlapping physical and biochemical properties. Bertolini and his group (1994) have located lipase genes present in four strains (ATCC 34614, NRCC 205002, NRRLY-552 and NRRLY -553) of Geotrichumcandidum by molecular cloning by polymerase chain reaction. Each strain contains two lipase genes that are closely related to lipase I and II of Geotrichumcandidum ATCC 34614, so far investigated. Each lipase - gene family exihibits sequence variation (polymorphism), which is confirmed by southern analysis as well. Only two genes are found in each of the strain investigated and the biochemical studies also suggest the existence of lipase with at least two different substrates specificities. Most of the amino acid substitutions are located on the protein surface; some are present in structural features possibly involved in determining substrate specificity. The conflicting reports about existence of more than two lipase isoforms probably originate from differential expression of these genes in different culture conditions, heterogenesis in posttranslational modification and different efficiency of 
Table 5.Yeasts that harbour lipases gene families along with the number of lipases genes contributing towards each family.

\begin{tabular}{|c|c|c|}
\hline Name & Number of lipase encoding genes & Reference \\
\hline Candida albicans & 10 & Hube et al. 2000 \\
\hline Candida antarctica & 2 & $\begin{array}{l}\text { Høegh et al. } 1995 \\
\text { Rotticci et al. } 2001\end{array}$ \\
\hline Candida rugosa ATCC 14380 & 5 & Lotti et al. 1993 \\
\hline Candida deformans CBS 2071 & 3 & Bigey et al. 2003 \\
\hline $\begin{array}{l}\text { Geotrichum candidum } \\
\text { ATCC } 34614 \\
\text { NRCC } 205002 \\
\text { NRRL Y-552 } \\
\text { NRRL Y-533 }\end{array}$ & $\begin{array}{l}2 \\
2 \\
2 \\
2\end{array}$ & $\begin{array}{l}\text { Shimada et al. } 1990 \\
\text { Bertolini et al. } 1994 \\
\text { Bertolini et al. } 1994 \\
\text { Bertolini et al. } 1994\end{array}$ \\
\hline Trichosporonfermentans WU-C12 & 2 & Arai et al. 1997 \\
\hline Yarrowia lipolytica & 3 & Pignede et al. $2000 a$ \\
\hline
\end{tabular}

purification. Catoni et al. (1997) studied Geotrichumcandidum ATCC 335426 lipases A and B in $P$. pastoris. The sequences encoding mature lipases were fused in frame with the $\mu$-factor signal sequence and expressed under control of the AOX 1 promoter. Depending on the clones, the extracellular production of lipases $\mathrm{A}$ and $\mathrm{B}$ varied from $1 \mathrm{U} / \mathrm{ml}$ to $23 \mathrm{U} / \mathrm{ml}$ and $1 \mathrm{U} / \mathrm{ml}$ to $50 \mathrm{U} / \mathrm{ml}$, respectively. Optimization studies of recombinant lipase $\mathrm{B}$ production increased the activity to $200 \mathrm{U} / \mathrm{ml}$ of culture medium.

\section{Trichosporon}

Arai et al. (1997) isolated a cDNA clone encoding extracellular lipase ofTrichosporonfermentans WU-C12 (TFL I) by using $0.8 \mathrm{~kb}$ fragment amplified by PCR with synthetic nucleotide corresponding to partial amino acid of TFL I. On characterization it emerged the cDNA clone contains 1689 bases long ORF, which encodes 563 amino acids from the ATG initiation codon. Two potential sites for $\mathrm{N}$ glycosylation are found in this enzyme. Complete data search indicated high homology between TFL and Geotrichumcandidm lipase (GC ATCC 34614). Mature lipase I (TFL I) ofTrichosporonfermentans WU-C12 Is 84 $\%$ and $99.5 \%$ homologus to GCL I and II respectively at amino acid level and nucleotide sequence identities are $86.1 \%$ and $99.9 \%$ respectively (Arai et al. 1997). There are differences of only 3 amino acid residues at position 23-25 between TFL GCL II and I. The deduced amino acid sequence of mature TFL I share $41 \%$ and $42.3 \%$ overall identity with those of lipase III and IV from Candida cylindracea earlier cloned by Lotti's group.

\section{Yarrowia lipolytica and other yeasts}

Several lipases have been detected in Yarrowia lipolytica, including intracellular, membrane-bound, and extracellular enzyme. Three lipase encoding genes have been isolated from Yarrowia lipolytica, lip1 code for 486-aa and lip3 which codes for 498-aa lipase. Lip1 and lip3 are reported to be intracellular but lip2 which has been isolated by Pignede et al. 2000a and Pignede et al. 2000b, belongs to the class of extra-cellular lipases. PCR and Southern analysis show that unlike some yeasts, like Candida rugosa and $G$. candidum in which several highly homologous genes are present $Y$. lipolytica has a single gene encoding extracellular lipase. This is also supported by the low residual extracellular lipase activity(less than $0.5 \% \mathrm{U} / \mathrm{ml}$ ) (Pignede et al. 2000a and Pignede et al. 2000b).

The phospholipase encoding cDNA of Kluyveromyces lactis was identified by combination of several procedures and sequence was designated as KILB. KIPLB encods a protein consisting of 640 amino acids. The deduced amino acid sequence showed $66.7 \%$ similarity with the TrichosporondelbrueckiiPLB.The amino acid sequence contained the lipase consensus sequence (G-X-S-X-G) and the catalytic aspartic acid motif.

The lipase-encoding Arxulaadeninivorans, ALIP1 gene was isolated using fragments of lipase isolates obtained by trypsin digestion for the definition of oligonucleotide primers in a PCR screening approach (Boer et al. 2005). The gene harbours an ORF of 1347 bp encoding a 420 amino acid protein of some $50 \mathrm{kDa}$ preceded by an $\mathrm{N}$ terminal 28 prepro-secretion sequence. The deduced amino acid sequence was found to be similar to the lipases from Candida albicans and Candida parapsilosis (34-38\% identity) and more distantly related to other lipases. The 
sequence contains the consensus pentapeptide motif (-Gly$\mathrm{X}$-Ser-X-Gly-) that forms a part of the interfacial lipid recognition site in lipases. The expression of the gene is regulated by carbon source. In media supplemented with Tween 20, induction of the ALIP1 gene and accumulation of the encoded lipase in the medium is observed, thus demonstrating gene regulation by lipophilic compounds. The enzyme is dimericwith $\mathrm{pH}$ optimum at $\mathrm{pH} 7.5$ and a temperature optimum at $30^{\circ} \mathrm{C}$.

\section{CONCLUDING REMARKS}

Like most other organisms lipases are ubiquitous in yeasts. Lipases are amongst the most important biocatalysts that carry out novel reactions in aqueous and non - aqueous media. They show wide variety of chemio-, regio- and enantioselective transformations. The ease in handling them, their broad substrate tolerance, high stability under varied temperature and solvents, high enantioselectivity and easy availability account for their wide spread popularity. As a result, today they have earned immense application in different areas of industrial microbiology and biotechnology where they display amazing versatility in catalytic behaviour. Yeast lipases are quite relevant to biotechnology industries and attract special attention, as yeast products have been consumed by man since ages and are considered safe and natural. Yeast lipases by and large are extracellular, monomericglycoproteins though there are some reports like in Yarrowia lipolytica wherein lipase two out of three isozymes present are cell bound as well as intacellular in nature. The molecular weight of various yeast lipases reported is between $\sim 33$ to $\sim 65 \mathrm{kD}$. Nucleotide sequence homology study of various cloned lipases from yeasts suggest that they lipase isozymes are produced by different genes. Post transcriptional and post translational modifications do also contribute towards production of various isoenzymes. In two widely studied lipase producing yeasts Candida rugosanadGeotrichumcandidum the lipase genes have been located on the same chromosome. These results have led to the presumption, that the various lipase encoding genes have perhaps resulted from gene duplication. More than $50 \%$ of yeasts produce lipases isozymes encoded by different genes constituting the lipase gene families. Like many other organisms including mammals presence of lipase gene families is quite prevalent in yeasts and at present Candida albicans leads with 11 lipase encoding genes. Members of various lipase gene families have been tabulated in Table 5.

\section{FUTURE PROSPECTS}

Compared to enormous potential lipases in general and yeast lipases in particular, their actual use in biotechnology industry at present is almost negligible. Hydrolysis of fats and oils is still being carried out by the conventional emulsion system and not with the use of lipases. The technology has not advanced to provide substitutes of the conventional chemical process. However one yeast enzyme,
CCL is being used for splitting oil and use of fatty acids produced for production of soaps (Reetze and Schimossek, 1996; Saxena et al. 1999). Introduction of new generation thermostable yeast lipases can tilt economic balance in favour of lipases. Novel lipases can also be used for the synthesis of whole range of amphoteric biodegradable surfactants namely amino acid based ester amides. The prospects of industrial application of lipases are bright. However it calls for discovering novel lipases by extensive screening and transformation of the known ones by genetic manipulations. Greater understanding of all aspects of lipase production and upstream, downstream processing of factors effecting lipase activity and stability. The mechanism by which these factors influence the threedimensional structure of lipases and their ability to catalyse. Factors such as immobilization and the nature of organic solvents used also affect the catalytic efficiency of lipase. Thorough understanding of the factors can help in the development of tailor made lipases for specific application and in long run open up new vistas.

Biotech industry can be classified into three groups, which are listed below.

1. Industries producing high volume, and low value products e.g. ethanol, high fructose syrup.

2. Those making high volume and moderate value commodities e.g. organic acids, amino acids, food products polymers.

3. Industries manufacturing low volume, high value products e.g. pharmaceuticals, vitamins, enzymes etc.

Whatever be the volume or value of the product of industry most of these are used for consumption. It is not necessary to emphasize that use of yeasts in manufacture of consumable items is safe. In fact yeast has been used since ages in manufacture of food products like cheese, yogurt, curd, bread etc. and are considered natural.

Dozen of lipases including yeast lipases are now commercially available nevertheless those employed in large - scale industrial process and products are still limited to few cases. This is mainly due to high price/ low availability or non-optimal operational features of naturally available enzymes. Perspectives in the use of lipases as industrial catalysts strongly rely on the production of recombinant enzymes with biochemical and catalytic features improved by protein engineering methods.

\section{REFERENCES}

ANTONIAN, E. Recent advances in the purification characterisation and structure determination of lipases. Lipids,1988, vol.23, no.12, p. 1101-1106.

ARAI, Tsuyoshi; YUSA, Satoshi; KIRIMURA, Kohtaro and USAMI, Shoji. Cloning and sequencing of the cDNA encoding lipase I from Trichosporonfermentans WU-C12. 
FEMS Microbiology Letters, July 1997, vol. 152, no. 1, p. 183-188.

ARPIGNY, Jean Louis and JAEGER, Karl-Erich. Bacterial lipolytic enzymes: Classification and properties. Biochemical Journal, October 1999, vol. 343, no.1, p. 177183.

BATENBURG, A.M.; EGMOND, M.R.; FRENKEN, L.G.J. and VIRRIPS, C.T. Enzymes and enzymatic detergent composition.European patent 0407225A1, 1991.

BENJAMIN, Sailas and PANDEY, Ashok. Isolation and characterization of three distinct forms of lipases from Candida rugosa produced in solid state fermentation. Brazilian Archives of Biology and Technology, June 2001, vol. 44, no. 2, p. 213-221.

BENJAMIN, Sailas and PANDEY, Ashok. Candida rugosa lipases: Molecular biology and versatility in biotechnology. Yeast, September1998, vol. 14, no. 12, p. 1069-1087.

BERTOLINI, Maria Célia; LARAMEE, Louise; THOMAS, David Y.; CYGLER, Miroslaw; SCHRAG, Joseph D. and VERNET, Thierry. Polymorphism in the lipase gene of Geotrichumcandidum strains. European Journal of Biochemistry/FEBS, January 1994, vol. 219, no. 1-2, p. 119-125.

BIGEY, Frédéric; TUERY, Karine; BOUGARD, Daisy; NICAUD, Jean-Marc and MOULIN, Guy. Identification of triacylglycerol lipase gene family in Candida deformans: Molecular cloning and functional expression. Yeast, February 2003, vol. 20, no. 3, p. 233-248.

BOER, Erik; MOCK, Hans Peter; BODE, Rüdiger; GELLISSEN, Gerd and KUNZE, Gotthard. An extracellular lipase from the dimorphic yeast Arxulaadeninivorans: molecular cloning of the ALIP1 gene and characterization of the purified recombinant enzyme. Yeast, May 2005, vol. 22, no. 7, p. 523-535.

BROCCA,Stefania; SECUNDO, Francesco; OSSOLA, Mattia; ALBERGHINA, Lilia; CARREA, Giacomo and LOTTI, Marina. Sequence of the lid affects activity and specificity of Candida rugosa lipase isoenzymes. Protein Science, July2003, vol.12, p. 2312-2319.

BROCCA, Stefania; SCHMIDT-DANNERT, Claudia; LOTTI, Marina; ALBERGHINA, Lilia and SCHMID, Rolf D. Design total synthesis and functional overexpression of the Candida rugosa Lip1 gene coding for a major industrial lipase. Protein Science, June 1998, vol. 7, no. 6, p. 14151422.

BROCCA, Stefania; GRANDORI, Rita; BREVIARIO, Diego and Lotti, Marina.Localization of lipase genes on Candida rugosa chromosomes. Current Genetics, October 1995, vol. 28, no. 5, p. 454-457.
CATONI, E.; SCHMIDT-DANNERT, Claudia; BROCCA, Stefania and SCHMID, Rolf D. Overexpression of lipase A and B of Geotrichumcandidum in Pichiapastoris: highlevel production and some properties of functional expressed lipase B. Biotechnology Techniques, September 1997, vol. 11, no. 9, p. 689-695.

CHANG, C-R.; CHOU, J-S.and SHAW, F-J. Multiple forms and functions of Candida rugosa lipase. Biotechnology and Applied Biochemistry, 1994, vol. 19, p. 93-97.

CHARTON, E.; DAVIES, C.and MACRAE, A.R. Use of specific polyclonal antibodies to detect heterogeneous lipases from Geotrichumcandidum.BiochimicaetBiophysicaActa, July 1992, vol. 29, no. 1127(2), p.191-8.

CHEN, Jiacong; SHIMURA, Susumu; KIRIMURA, Kohtaro and USAMI, Shoji.Lipase production by hydrocarbons by Trichosporonfermentans WU-C12 in presence of surfactants. Bioscience, Biotechnology and Biochemistry, 1994, vol. 58, p. 773-775.

CHEN, Jiacong; SHIMURA, Susumu; KIRIMURA, Kohtaro and USAMI, Shoji.Enhancement of lipase production from hydrocarbons by mutation of Trichosporonfermentans. Applied Microbiology and Biotechnology, March1993, vol. 38, no. 6, p. 714-718.

CHEN, J.; ISHII, T.; SHIMURA, S.; KIRIMURA, K. and USAMI, S. Lipase production by Trichosporonfermentans WU-C12, a newly isolated yeast. Journal of Fermentation and Bioengineering, 1992, vol. 73, p. 412-414.

DESTAIN, J.; ROBLAIN, D. and THONART, P. Improvement of lipase production from Yarrowia lipolytica. Biotechnology Letters, February 1997, vol. 19, no. 2, p. 105-107.

DHARMSTHITI, Saovanee and AMMARANOND, Palanee. Purification and Characterization of lipase from a raw-milk yeast (Trichosporonasteroides). Biotechnology and Applied Biochemistry, October 1997, vol. 26, no. 2, p. 111-116.

FU, Y.U.C.; IBRAHIM, A.S.; FONZI, W.; ZHOU, X.; RAMOS, C.F. and GHANNOUM, A.M. Cloning and characterization of a gene (LIPI) which encodes a lipase from the pathogenic yeast Candida albicans. Microbiology, February 1997, vol. 143, no. 2, p. 331-340.

GANDHI ,Neena N. Applications of Lipase. JAOCS, Journal of the American Oil Chemists' Society, June 1997, vol. 74, no. 6, p. 621-634.

GUSTAVSSON, M.T.; PERSSON, P.V.; IVERSEN, T.; HULT, K. and MARTINELLE, M. Polyester coating of cellulose fiber surfaces catalyzed by a cellulose-binding module-Candida antarctica lipase $B$ fusion 
protein.Biomacromolecules, January 2004, vol. 5, no. 1, p. 106-112.

HERNAIZ, M.J.; SANCHEZ, M.J.M. and SINISTERRA, J.V. Hydrolysis of $(\mathrm{R}, \mathrm{S}) 2$ aryl propionic esters by pure lipase B from Vandidacylindracea. Journal of Molecular Catalysis A: Chemical, 1997, vol. 19, p. 303-306.

HUBE, Bernhard; STEHR, Frank; BOSSENZ, Michael; MAZUR, Anna; KRETSCHMAR, Marianne and SCHAFER, Wilhelm. Secreted lipases of Candida albicans: cloning, characterization and expression analysis of a new gene family with at least ten members. Archives of Microbiology, 2000, vol. 174, no. 5, p. 362-374.

HØEGH, I.; PATKAR, S.; HALKIER, T. and HANSEN, M.T. Two lipases from Candida antarctica: cloning and expression in Aspergillus oryzae. Canadian Journal of Botany, 1995, vol. 73, p. S869-S875.

JACOBSEN, T. and POULSEN, O.M. Separation and characterization of $61-$ and $57-\mathrm{kDa}$ lipases from Geotrichumcandidum ATCC 66592. Canadian Journal of Microbiology, January 1992, vol. 38, no. 1, p. 75-80.

JAEGER, K.E.; DIJKSTRA, B.W. and REETZ, M.T. Bacterial biocatalysts: Molecular biology three-dimensional structures and biotechnological applications of lipases. Annual Review Microbiology, October 1999, vol.53, p. 315351.

KADEMI, A.; LEE, B. and HOUDE, A. Production of heterologous microbial lipases by yeasts. Indian Journal of Biotechnology, July 2003,vol.2, no. 3, p. 346-355.

KAKUGAWA, Koji; SHOBAYASHI, Megumi; SUZUKI, Osamu and MIYAKAWA, Tokichi. Purification and characterization of a lipase from the glycolipid-producing yeast Kurtzmanomyces sp. I-11. Bioscience, Biotechnology and Biochemistry, May 2002, vol. 66, no. 5, p. 978-985.

KAZANINA, G.A.; PETROVA, L.A.; SELEZNEVA, A.A.; RUBAN, E.L. and VOLKOVA, I.M. Isolation and characterization of lipase from Geotrichum asteroids FKM F-144.PrikladnaiaBiokhimmiia I Mikrobiologiia, JulyAugust 1981, vol. 17, no. 4, p. 516-522.

KAZLAUSKAS, R.J. and BORNSCHEUER, U.T. Biotransformations by lipases. In: REHM, H.J.; REED, G.; PAHLER, A.; STADLER, P.J.W. and KELLY, D.R. Biotechnology, 1998, vol. 8. VCH, Weinheim. FALTA NUM PAGINAS.

KONTKANEN, H.; TENKANEN, M.; FAGERSTROM, R. and REINIKAINEN, T. Characterisation of steryl esterase activities in commercial lipase preparations. Journal of Biotechnology, February 2004, vol. 108, no. 1, p. 51-59.

KUNO, H. and OTA, Y. The new method for the purification of extracellular lipases from Yarrowia
(Saccharomycopsis) lipolytica and some properties of lipase American Journal Fac. Appl. Biol. Sci. 1996, vol. 35, p. 191-197.

LAZAR, G. and SCHRODER, F.R. NAME OF CHAPTER In: WINKELMANN, G. ed. Microbialdegradation of natural products. VCH, Weinheim, 1992, p. 267-291.

LOPEZ, N.; PERNAS, M.A.; PASTRANA, L.M.; SANCHEZ, A.; VALERO, F. and RUA, M.L. Reactivity of pure Candida rugosa lipase isoenzymes (Lip1, Lip2 and Lip3) in aqueous and organic media. Influence of the isoenzymatic profile on the lipase performance in organic media. Biotechnology Progress, January 2004, vol. 20, no. 1, p. 65-73.

LOTTI, M. and ALBERGHINA, L. Candida rugosa lipases: From molecular evolution, analysis to the design of a synthetic gene. In: Protein Engineering in Industrial Biotechnology. Harwood Academic Publishers Australia. 2003, p. 63-75.

LOTTI, Marina; BROCCA, Stefania and PORRO, D. High lipase production by Candida rugosa is associated with G1 cells. A flow cytometry study. Biotechnology Letters, 2001, vol. 23 , no. 21 , p. $1803-1808$.

LOTTI. Marina; GRANDOSI, Rita; FUSETTI, Fabrizia; LONGHI, Sonia; BROCCA, Stefania.; TRAMONTANA, Anna and ALBERGHINA, Lilia. Cloning and analysis of Candida cylindracea lipase sequence. Gene, February 1993, vol. 124, no. 1, p. 45-55.

MACRAE, A.R. and HAMMOND, R.C. Present and future applications of lipases. Biotechnology Genetics and Engineering Review, 1985, vol. 3, p. 193-217.

NAGAO, T.; SHIMADA, Y.; SUGIHARA, A. and TOMINAGA, Y. Cloning and sequencing of two chromosomal lipase genes from Geotrichumcandidum. Journal of Biochemistry, 1993, vol. 103, no. 6, p. 776-780.

NEUGNOT, Virginie; MOULIN, Guy; DUBRENG, Eric and BIGEY, Frédéric. The lipase /acyltransferasefrom Candida parapsilosis: Molecular cloning and characterization of purified recombinant enzymes. European Journal of Biochemistry, March 2002, vol. 269, no. 6, p. 1734-1745.

NOVOTNY, C.; DOLEZALOVA, L. and LIEBLOVA, J. Dimorphic growth and lipase production in lipolytic yeasts. Folia Microbiologica, 1994, vol. 39, no. 1, p. 71-73.

OHAMA, T.; SUZUKI, T.; MORI, M.; OSAWA, S.; VEDA, T.; WATANABE, $\mathrm{K}$ and NAKASE, T. Nonuniversal decoding of the leucine codon CUG in several Candida species.Nucleic acids Research, August 1993, vol.21, no. 17, p. 4039-4045. 
OISHI, Hideki; MORIMOTO, Takahiro; WATANABE, Yasuo and TAMAI, Youichi.Purification and characterization of phospholipase B from Kluyveromyces lactis and cloning of phospholipase B gene. Bioscience, Biotechnology and Biochemistry, January 1999, vol. 63, no. 1, p. 83-90.

OTA, Yasuhide; SAWAMOTO, Takeshi and HASUO, Masaki.Tributyrin specifically induces a lipase with a preference for the sn-2 position of triglyceride in Geotrichum sp. FO401B. Bioscience, Biotechnology and Biochemistry, November 2000, vol. 64, no. 11, p. 2497 2499.

OTA, Y.; OIKAWA, S.; MORIMOTO, Y. and MINODA, Y. Nutritional factors causing mycelial development of Saccharomycopsis lipolytica. Agricultural and Biological Chemistry, 1984, vol. 48, p. 1933-1940.

OTA, Y.; GOMI, K.; KATO, S.; SUGIURA, T. and MINODA, Y. Purification and some properties of cellbound lipase from Saccharomycopsis lipolytica. Agricultural and Biological Chemistry, 1982, vol. 46, p. 2885-2893.

OTA, Y. and YAMADA, K. Lipase from Candida paralipolytica: Part 1 Anionic surfactant as the essential activator in the systems emulsified by polyvinyl alcohol. Agricultural and Biological Chemistry, 1966, vol.30, p. 351-358.

PANDEY, Ashok; BENJAMIN, Sailas; SOCCOL, Carlos R.; NIGAM, Poonam; KRIEGER, Nadia and SOCCOL, Vanete T.The realm of microbial lipases in biotechnology. Biotechnology and Applied Biochemistry, April 1999, vol. 29, no. 2, p. 119-131.

PASSOLUNGHI, S.; BROCCA, S.; CANNIZZARO, L.; PORRO, D. and LOTTI, M. Monitoring the transport of recombunant Candida rugosa lipase by a green fluorescent protein-lipase fusion. Biotechnology Letters, (2003, vol. 25, no. 22 , p. $1945-1948$.

PIERCE, G.E.; WICK, C.B. and PALMER, D.T. Unique microbial lipases with activity at temperatures and $\mathrm{pH}$ 's suitable for use in detergent. 1990 European Patent No. 0385401 .

PIGNEDE, G.; WANG, H.; FUDALEJ, F.; GAILLARDIN, C.; SEMAN, M. and NICAUD, J-M.Characterization of an extracellular lipase encoded by Lip2 in Yarrowia lipolytica. Journal of Bacteriology, May 2000a, vol. 182, no. 10, p. 2802-2810.

PIGNEDE, G.; WANG, H.; FUDALEJ, F.; SEMAN, M.; GAILLARDIN, C. and NICAUD, J-M.Autocloning and amplification of lip2 in Yarrowia lipolytica. Applied and Environmental microbiology, 2000b, vol. 66, no. 8, p. 3283-3289.
ROTTICCI-MULDER, Johanna C.; GUSTAVSSON, Malin; HOLMQUIST, Mats; HULT, Karl and MARTINELLE, Mats. Expression in Pichiapastoris of Candida antarctica lipase B and lipase B fused to a cellulose - binding domain. Protein Expression and Purification, April 2001, vol. 21, no. 3, p. 386-392.

REDONDO, O.; HERRERO, A.; BELLO, J.F.; ROIG, M.G.; CALVO, M.V.; PLOU, F.J. and BURGUILLO, F.J. Comparative kinetic study of lipases A and B from Candida rugosa in the hydrolysis of lipid P-nitrophenyl esters in mixed micells with triton X-100. Biochimica et BiophysicaActa (BBA)-General Subjects, January 1995, vol. 1243, no. 1, p. 15-24.

REETZ, M.T. and SCHIMOSSEK, K. Lipase-catalyzed dynamic kinetic resoultion of chiral amines: use of palladium as the racemization catalyst. Chimia. 1996, vol. 50, no. 12 , p. 668-669.

SAXENA, R.K.; GOSH, P.K.; GUPTA, R.; DAVIDSON, W. Sheba; BRADOO, Sapna and GULATI, Ruchi. Microbial lipases: potential biocatalysts for the future industry. Current Science, July 1999, vol. 77, no. 1, p. 101115.

SCHMIDT, Rolf D. and VERGER, Robert. Lipases: Interfacial enzymes with attractive applications. AngewandteChemie (International ed. in English), July1998, vol. 37, no. 12, p. 1608-1633.

SHAW, J.F. and CHANG, C.H. Characterization of three distinct forms of lipolytic enzyme in a commercial Candida lipase prepration. Biotechnology Letters, November 1989, vol. 11, no. 11, p. 779-784.

SHELDON, R.A. Chirotechnology-industrial synthesis of optically-active compounds.Marcel Dekker Ltd., New York. 1993.448 p. ISBN 0824791436.

SHIMADA, Y.; SUGIHARA, A.; TOMINAGA, Y. and IIZUMI, T. cDNA cloning and characterization of Geotrichumcandidum lipase II. Journal of Biochemistry, May 1990, vol. 107, no. 5, p. 703-707.

SHIMADA, Y.; SUGIHARA, A.; TOMINAGA, Y.; IIZUMI, T. and TSUNASAMA, S. cDNA molecular cloning of Geotrichumcandidum lipase. Journal of Biochemistry, September 1989, vol. 106, no. 3, p. 383-388.

SIDEBOTTOM, C.M.; CHARTON, E.; DUNN, P.P.; MYCOCK, G.; DAVIES, C.; SUTTTON, J.; MACRE, A.R. and SLABAS, A.R. Geotrichumcandidum produces sevelar lipases with markedly different substrate specificities. European Journal of Biochemistry, 1991, vol. 202, p. 485-491.

SMIDT, H.; FISCHER, A.; FISCHER, P. and SCHMID, R.D. Preparation of optically pure chiral amines by lipase- 
catalyzed enantioselective hydrolysis of $N$-acyl-amines. Biotechnology Techniques, 1996, vol. 10, no. 5, p. 335-338.

SUGIHARA, A.; SHIMADA, Y. and TOMINAGA, Y. Separation and characterization of two molecular forms of Geotrichumcandidum lipase. Journal of Biochemistry, 1990, vol. 107, no. 3, p. 426-430.

SUGIURA, T.; OTA, Y. and MINODA, Y. Partial characterisation of cell-bound lipase of Candida paralipolytica. Agricultural and Biological Chemistry, 1976, vol. 40, p. 2479-2480.

STEHR, Frank; FELK, Angelika; GACSER, Attila; KRETSCHMAR, Marianne; MAHNSS, Birgit; NEUBER, Karsten; HUBE, Bernhard and SCHAFER, Wilhelm. Expression analysis of Candida albicans lipase gene family during experimental infections and in patient samples. FEMS Yeast Research, January 2004, vol. 4, no. 4-5, p. 401-408.

TOROSSIAN, K. and BELL, A.W. Purification and characterization of acid resistant triacylglycerol lipase from Aspergillus niger. Biotechnology and Applied Biochemistry, 1991, vol. 13, p. 205-211.

TSUJISAKA, Y.; IWAI, $M$. and TOMINASA, Y. Purification, crystallization and some properties of lipase from Geotrichumcandidum link. Agricultural and Biological Chemistry, 1973, vol. 37, p. 1457-1464.

UPPENBERG, Jonas; PATKAR, Shamkant; BERGFORS, Terese and JONES, T.Alwyn.Crystilization and preliminary X-ray studies of lipase B from Candida Antarctica. Journal of Molecular Biology, January 1994,vol. 235, no. 2, p. 790792.

VEERARAGAVAN, K.; COLPITTS, T. and GIBBS, B.F. Purification and characterization of two distinct lipases from Geotrichumcandidum.BiochimicaetBiophysicaActa, May 1990, vol. 1, no. 1, p. 26-33.

VEERARAGAVAN, K. and GIBBS, B.F. Detection and partial purification of two lipases from Candida rugosa. Biotechnology Letters, 1989, vol. 11, p. 345-348.

VERGER, R. Interfacial activation of lipases: facts and artefacts. Trends in Biotechnology, January 1997, vol. 15, no. 1, p. 32-38.

VERNET, T.; ZIOMEK, E.; RECKTENWALD, A.; SCHRAG, J.D.; DE MONTIGNY, C.; TESSIER, D.C.; THOMAS, D.Y. and CYGLER, M. Cloning and expression of Geotrichumcandidum lipase II gene in yeast. Probing of the enzyme active site by site-directed mutagenesis. Journal of Biological Chemistry, December 1993, vol. 15, no. 268(35), p. 26212-26219.

YADAV, Raman P.; SAXENA, Rajendran K.; GUPTA, Rani and DAVIDSON, W. Sheba.Purification and characterization of a regiospecific lipase from Aspergillus terreus. Biotechnology and Applied Biochemistry, December 1998, vol. 28, no. 3, p. 243-249.

WANG, K.; ZHANG, Y. and Yuan, C. Enzymatic synthesis of phosphocarnitine, phosphogabob and fosfomycin. Organic and Biomolecular Chemistry, October 2003, vol. 1, no. 20, p. 3564-3569. 